\title{
Front Matter: 8087
}

, "Front Matter: 8087," Proc. SPIE 8087, Clinical and Biomedical Spectroscopy and Imaging II, 808701 (7 July 2011); doi: 10.1117/12.902367

SPIE. Event: European Conferences on Biomedical Optics, 2011, Munich, Germany 


\title{
PROGRESS IN BIOMEDICAL OPTICS AND IMAGING
}

Vol. 12, No. 41

\section{Clinical and Biomedical Spectroscopy and Imaging II}

\author{
Nirmala Ramanujam \\ Jürgen Popp \\ Editors
}

24-26 May 2011

Munich, Germany

Sponsored by

SPIE

The Optical Society of America (United States)

Cooperating Organisations

Deutsche Gesellschaft für Lasermedizin (Germany)

Visions for Better Healthcare-Biophotonics Research Program (Germany)

With Support From

Air Force Office of Scientific Research (United States)

Photonics 4 Life-European Network of Excellence for Biophotonics (Germany)

Student Award Sponsors

Toptica Photonics AG (Germany)

ThorLabs (United Kingdom) 
The papers included in this volume were part of the technical conference cited on the cover and title page. Papers were selected and subject to review by the editors and conference program committee. Some conference presentations may not be available for publication. The papers published in these proceedings reflect the work and thoughts of the authors and are published herein as submitted. The publisher is not responsible for the validity of the information or for any outcomes resulting from reliance thereon.

Please use the following format to cite material from this book:

Author(s), "Title of Paper," in Clinical and Biomedical Spectroscopy and Imaging II, edited by Nirmala Ramanujam, Jürgen Popp, Proceedings of SPIE Vol. 8087 (SPIE, Bellingham, WA, 2011) Article CID Number.

ISSN 1605-7422

ISBN 9780819486844

\section{Copublished by}

\section{SPIE}

P.O. Box 10, Bellingham, Washington 98227-0010 USA

Telephone +1 3606763290 (Pacific Time) · Fax +1 3606471445

SPIE.org

and

Optical Society of America

2010 Massachusetts Ave., N.W., Washington, D.C., 20036 USA

Telephone 1 202/223-8130 (Eastern Time) · Fax 1 202/223-1096

http://www.osa.org

Copyright (C) 2011, Society of Photo-Optical Instrumentation Engineers and Optical Society of America

Copying of material in this book for internal or personal use, or for the internal or personal use of specific clients, beyond the fair use provisions granted by the U.S. Copyright Law is authorized by SPIE subject to payment of copying fees. The Transactional Reporting Service base fee for this volume is $\$ 18.00$ per article (or portion thereof), which should be paid directly to the Copyright Clearance Center (CCC), 222 Rosewood Drive, Danvers, MA 01923. Payment may also be made electronically through CCC Online at copyright.com. Other copying for republication, resale, advertising or promotion, or any form of systematic or multiple reproduction of any material in this book is prohibited except with permission in writing from the publisher. The CCC fee code is 1605 $7422 / 11 / \$ 18.00$.

Printed in the United States of America.

Publication of record for individual papers is online in the SPIE Digital Library.

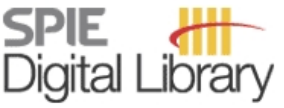

SPIEDigitallibrary.org

Paper Numbering: Proceedings of SPIE follow an e-First publication model, with papers published first online and then in print and on CD-ROM. Papers are published as they are submitted and meet publication criteria. A unique, consistent, permanent citation identifier (CID) number is assigned to each article at the time of the first publication. Utilization of CIDs allows articles to be fully citable as soon as they are published online, and connects the same identifier to all online, print, and electronic versions of the publication. SPIE uses a six-digit CID article numbering system in which:

- The first four digits correspond to the SPIE volume number.

- The last two digits indicate publication order within the volume using a Base 36 numbering system employing both numerals and letters. These two-number sets start with 00, 01, 02, 03, 04, $05,06,07,08,09,0 A, O B \ldots$ OZ, followed by 10-1Z, 20-2Z, etc.

The CID number appears on each page of the manuscript. The complete citation is used on the first page, and an abbreviated version on subsequent pages. Numbers in the index correspond to the last two digits of the six-digit CID number. 


\section{Contents}

xiii Conference Committee

$\mathrm{xV}$ Introduction

\section{MINIMALLY INVASIVE DIAGNOSTICS/LABORATORY MEDICINE I}

808704 Molecular histopathology by nonlinear interferometric vibrational imaging (Invited Paper) [8087-01]

S. A. Boppart, Univ. of Illinois at Urbana-Champaign (United States)

808706 Raman spectra classification with support vector machines and a correlation kernel [8087-03]

A. Kyriakides, Univ. of Cyprus (Cyprus); E. Kastanos, Univ. of Nicosia (Cyprus);

K. Hadjigeorgiou, C. Pitris, Univ. of Cyprus (Cyprus)

808707 The multifunctional application of microfluidic lab-on-a-chip surface enhanced Raman spectroscopy (LOC-SERS) within the field of bioanalytics [8087-04]

A. März, B. Mönch, A. Walter, T. Bocklitz, W. Schumacher, P. Rösch, M. Kiehntopf, Friedrich-Schiller-Univ. Jena (Germany); J. Popp, Friedrich-Schiller-Univ. Jena (Germany) and Institute of Photonic Technology (IPHT) (Germany)

\section{MINIMALLY INVASIVE DIAGNOSTICS/LABORATORY MEDICINE II}

808708 Bacterial identification in real samples by means of micro-Raman spectroscopy (Invited Paper) [8087-05]

P. Rösch, S. Stöckel, S. Meisel, A. Boßecker, U. Münchberg, S. Kloß, W. Schumacher, Friedrich-Schiller-Univ. Jena (Germany); J. Popp, Friedrich-Schiller-Univ. Jena (Germany) and Institut für Photonische e. V. (Germany)

\section{BIOSPECTROSCOPY AND POC DIAGNOSTICS I}

$8087 \mathrm{OA}$ Fluorescence spectroscopy and cryoimaging of rat lung tissue mitochondrial redox state [8087-07]

R. Sepehr, Univ. of Wisconsin-Milwaukee (United States); S. Audi, Marquette Univ. (United States) and Zablocki VA Medical Ctr. (United States); K. Staniszewski, S. Maleki, M. Ranji, Univ. of Wisconsin-Milwaukee (United States)

8087 OC Non-invasive SFG spectroscopy: a tool to reveal the conformational change of grafted chains due to bacterial adhesion [8087-09]

E. Bulard, H. Dubost, M.-P. Fontaine-Aupart, W. Zheng, ISMO-CNRS, Univ. Paris-Sud 11 (France); J.-M. Herry, M.-N. Bellon-Fontaine, R. Briandet, INRA-AgroParisTech (France); B. Bourguignon, ISMO-CNRS, Univ. Paris-Sud 11 (France) 
8087 OD Design and process development of a photonic crystal polymer biosensor for point-of-care diagnostics [8087-10]

F. Dortu, Multitel A.S.B.L. (Belgium); H. Egger, Bayer Technology Services GmbH (Germany); K. Kolari, T. Haatainen, VTT Technical Research Ctr. of Finland (Finland); P. Furjes, Z. Fekete, Research Institute for Technical Physics and Materials Science (Hungary); D. Bernier, Multitel A.S.B.L. (Belgium); G. Sharp, B. Lahiri, Univ. of Glasgow (United Kingdom); S. Kurunczi, Research Institute for Technical Physics and Materials Science (Hungary); J.-C. Sanchez, N. Turck, Univ. of Geneva (Switzerland); P. Petrik, D. Patko, R. Horvath, Research Institute for Technical Physics and Materials Science (Hungary); S. Eiden, Bayer Technology Services GmbH (Germany); T. Aalto, VTT Technical Research Ctr. of Finland (Finland); S. Watts, Stratophase Ltd. (United Kingdom); N. P. Johnson, Univ. of Glasgow (United Kingdom); R. M. De La Rue, Univ. of Glasgow (United Kingdom) and Univ. of Malaya (Malaysia);

D. Giannone, Multitel A.S.B.L. (Belgium)

8087 OE Effect of magnetic field in malaria diagnosis using magnetic nanoparticles [8087-11] Q. Liu, C. Yuen, Nanyang Technological Univ. (Singapore)

BIOSPECTROSCOPY AND POC DIAGNOSTICS II

8087 OF Collagen matrices as an improved model for in vitro study of live cells using Raman microspectroscopy (Invited Paper) [8087-12]

F. Bonnier, P. Knief, A. D. Meade, J. Dorney, K. Bhattacharya, F. M. Lyng, H. J. Byrne, Dublin Institute of Technology (Ireland)

\section{CLINICAL AND PRECLINICAL TISSUE CHARACTERIZATION I}

8087 0J Diagnostics of tumor cells by combination of Raman spectroscopy and microfluidics [8087-16]

U. Neugebaver, Institute of Photonic Technology (Germany) and Univ. Hospital Jena (Germany); S. Dochow, C. Krafft, Institute of Photonic Technology (Germany); T. Bocklitz, FSU Jena (Germany); J. H. Clement, Univ. Hospital Jena (Germany); J. Popp, Institute of Photonic Technology (Germany) and FSU Jena (Germany)

\section{CLINICAL AND PRECLINICAL TISSUE CHARACTERIZATION II}

8087 ON Breast imaging using the Twente photoacoustic mammoscope (PAM): new clinical measurements [8087-20]

M. Heijblom, Univ. Twente (Netherlands) and Medisch Spectrum Twente (Netherlands); D. Piras, E. Ten Tije, W. Xia, J. van Hespen, Univ. Twente (Netherlands); J. Klaase, F. van den Engh, Medisch Spectrum Twente (Netherlands); T. van Leeuwen, Univ. Twente (Netherlands) and Univ. of Amsterdam (Netherlands); W. Steenbergen, S. Manohar, Univ. Twente (Netherlands)

808700 Devising an endoluminal bimodal probe which combines autofluorescence and reflectance spectroscopy with high resolution MRI for early stage colorectal cancer diagnosis: technique, feasibility and preliminary in-vivo (rabbit) results [8087-21] A. Ramgolam, R. Sablong, Univ. de Lyon, CNRS, CREATIS (France); B. Bou-Saïd, INSA-Lyon, LaMCoS, CNRS, Univ. de Lyon (France); S. Bouvard, TIGER/IDEE Neuroscience Research Ctr. (France); H. Saint-Jalmes, LTSI, Univ. de Rennes 1 (France); O. Beuf, Univ. de Lyon, CNRS, CREATIS (France) 
8087 OP Infrared spectroscopy to estimate the gross biochemistry associated with different colorectal pathologies [8087-22]

J. J. Wood, C. Kendall, G. R. LLoyd, N. A. Shepherd, T. A. Cook, N. Stone, Gloucestershire Hospitals NHS Foundation Trust (United Kingdom)

\section{CLINICAL AND PRECLINICAL TISSUE CHARACTERIZATION III}

8087 OT Nano-sensitizers for multi-modality optical diagnostic imaging and therapy of cancer (Invited Paper) [8087-26]

M. Olivo, National Univ. of Ireland Galway (Ireland) and Royal College of Surgeons Ireland (Ireland) and National Univ. of Singapore (Singapore); S. S. Lucky, R. Bhuvaneswari,

N. Dendukuri, National Cancer Ctr. Singapore (Singapore)

\section{CLINICAL AND PRECLINICAL TISSUE CHARACTERIZATION IV}

8087 0X Raman and FTIR microspectroscopy for detection of brain metastasis [8087-30]

N. Bergner, Institute of Photonic Technology Jena (Germany); B. F. M. Romeike, R. Reichart, R. Kalff, Univ. Hospital Jena (Germany); C. Krafft, Institute of Photonic Technology, Jena (Germany); J. Popp, Institute of Photonic Technology, Jena (Germany) and Friedrich Schiller Univ. Jena (Germany)

8087 OY Fluorescence wavelength-time matrix acquisition for biomedical tissue diagnostics [8087-31]

W. R. Lloyd, R. H. Wilson, L.-C. Chen, Univ. of Michigan (United States); G. D. Gillispie, Fluorescence Innovations, Inc. (United States); M.-A. Mycek, Univ. of Michigan (United States)

808710 Dynamic multiphoton imaging of reversible and irreversible thermal changes in collagen tissues [8087-33]

V. A. Hovhannisyan, P.-J. Su, C.-Y. Dong, National Taiwan Univ. (Taiwan)

808711 Hyperspectral video endoscope for intra-surgery tissue classification using auto-fluorescence and reflectance spectroscopy [8087-34]

T. Arnold, M. De Biasio, R. Leitner, Carinthian Tech Research AG (Austria)

808712 Morphological and molecular analysis of the collagen fibers in inflammatory process [8087-35]

L. F. d. C. e. S. de Carvalho, Univ. Federal do ABC (Brazil) and Univ. Estadual Paulista (Portugal); M. G. O. Alves, Univ. Estadual Paulista (Portugal); C. A. Soares, Univ. Federal do ABC (Brazil); J. D. Almeida, Univ. Estadual Paulista (Portugal); H. da Silva Martinho, Univ. Federal do $A B C$ (Brazil)

808713 Optical spectroscopy for quantitative sensing in human pancreatic tissues [8087-36] R. H. Wilson, M. Chandra, W. Lloyd, L.-C. Chen, J. Scheiman, D. Simeone, B. McKenna, M.-A. Mycek, Univ. of Michigan, Ann Arbor (United States)

808714 Near-infrared raman spectroscopy for detection of gastric cancer peritoneal dissemination in vivo [8087-37]

J. Ma, Ocean Univ. of China (China); W. Mao, Qingdao Municipal Hospital (China); M. XU,

L. Gong, Y. Gao, H. Zhou, R. Zheng, Ocean Univ. of China (China) 
808716 Determination of chromophore concentrations from spatially resolved skin measurements [8087-39]

S. Andree, J. Helfmann, I. Gersonde, Laser- und Medizin-Technologie (Germany)

808717 Hyperspectral characterization of fluorophore diffusion in human skin using a sCMOS based hyperspectral camera [8087-40]

J. Hernandez-Palacios, Norsk Elektro Optikk AS (Norway) and Univ. of Oslo (Norway); I. J. Haug, Norwegian Univ. of Science and Technology (Norway); $\varnothing$. Grimstad, Trondheim Univ. Hospital (Norway); L. L. Randeberg, Norwegian Univ. of Science and Technology (Norway)

808718 Non-invasive imaging of skin cancer with fluorescence lifetime imaging using two photon tomography [8087-41]

R. Patalay, Imperial College London (United Kingdom) and Imperial College Healthcare NHS Trust (United Kingdom); C. Talbot, Y. Alexandrov, I. Munro, Imperial College London (United Kingdom); H. G. Breunig, K. König, JenLab GmbH (Germany); S. Warren, M. A. A. Neil, P. M. W. French, Imperial College London (United Kingdom); A. Chu, Imperial College Healthcare NHS Trust (United Kingdom); G. W. Stamp, Imperial College Healthcare NHS Trust (United Kingdom) and CRUK London Research Institute (United Kingdom); C. Dunsby, Imperial College London (United Kingdom) and Imperial College Healthcare NHS Trust (United Kingdom)

\section{SKIN DIAGNOSTICS AND THERAPY II}

8087 1A In-vivo morphologic and spectroscopic investigation of Psoriasis [8087-43]

D. Kapsokalyvas, R. Cicchi, LENS, Univ. of Florence (Italy); N. Bruscino, Univ. of Florence (Italy); D. Alfieri, Light4tech (Italy); D. Massi, Dept. of Critical Care Medicine and Surgery (Italy); T. Lotti, Univ. of Florence (Italy); F. S. Pavone, LENS, Univ. of Florence (Italy)

8087 1B In vivo TPEF-SHG microscopy for detecting collagen remodeling after laser micro-ablative fractional resurfacing treatment [8087-44]

R. Cicchi, D. Kapsokalyvas, M. Troiano, P. Campolmi, C. Morini, T. Lotti, F. S. Pavone, Univ. of Florence (Italy)

\section{CLINICAL AND PRECLINICAL DIAGNOSTICS I}

8087 ID Characterization of atherosclerotic plaque-depositions by infrared, Raman and CARS microscopy [8087-46]

C. Matthäus, G. Bergner, C. Krafft, B. Dietzek, Institut für Photonische Technologien e.V. (Germany); B. F. M. Romeike, B. R. Brehm, Friedrich-Schiller-Univ. of Jena (Germany); J. Popp, Institut für Photonische Technologien e.V. (Germany) and Friedrich-Schiller-Univ. of Jena (Germany) 
$8087 \mathrm{lF}$ Characterization of cytochrome $\mathrm{c}$ as marker for retinal cell degeneration by uv/vis spectroscopic imaging [8087-49]

J. Hollmach, J. Schweizer, G. Steiner, L. Knels, R. H. W. Funk, Dresden Univ. of Technology

(Germany); S. Thalheim, Thalheim Spezialoptik GmbH (Germany); E. Koch, Dresden Univ. of Technology (Germany)

8087 1G Detection of early metabolic alterations in the ocular fundus of diabetic patients by time-resolved autofluorescence of endogenous fluorophores [8087-50]

D. Schweitzer, Univ. of Jena (Germany); M. Klemm, Technical Univ. IImenau (Germany);

S. Quick, L. Deutsch, S. Jentsch, M. Hammer, J. Dawczynski, C. H. Kloos, U. A. Mueller, Univ. of Jena (Germany)

$8087 \mathrm{IH} \quad$ Using 2D correlation and multivariate analysis combined with plasmonic effects to expand the use of Raman microspectroscopy in biomedical applications [8087-51]

M. Marro, S. Raj, S. Rao, ICFO - The Institute of Photonic Sciences (Spain); A. Taubes,

P. Villoslada, IDIBAPS - Institut d'Investigacions Biomèdiques Agustí Pi Sunyer (Spain);

D. Petrov, ICFO - The Institute of Photonic Sciences (Spain) and ICREA - Institució Catalana

de Recerca i Estudis Avançats (Spain)

\section{CLINICAL AND PRECLINICAL DIAGNOSTICS III}

808711 Image-based fluorescence recovery after photobleaching (FRAP) to dissect vancomycin diffusion-reaction processes in Staphylococcus aureus biofilms [8087-52]

S. Daddi Oubekka, Institut des Sciences Moléculaires d'Orsay, CNRS, Univ. Paris-Sud (France); R. Briandet, INRA (France) and AgroParisTech (France); F. Waharte, CNRS - Institut Curie (France); M.-P. Fontaine-Aupart, K. Steenkeste, Institut des Sciences Moléculaires d'Orsay, CNRS, Univ. Paris-Sud (France)

$80871 \mathrm{~J}$ Time-resolved fluorescence spectroscopic investigation of cationic polymer/DNA complex formation [8087-53]

C. D'Andrea, A. Bassi, P. Taroni, IFN-CNR, Politecnico di Milano (Italy); D. Pezzoli,

A. Volonterio, G. Candiani, Politecnico di Milano (Italy)

$80871 \mathrm{M}$ Accuracy of vessel diameter estimated from a vessel packaging compensation in diffuse reflectance spectroscopy [8087-56]

I. Fredriksson, M. Larsson, T. Strömberg, Linköping Univ. (Sweden)

8087 iN DCT-SVM based multi-classification of mouse skin precancerous stages from autofluorescence and diffuse reflectance spectra [8087-57] F. Abdat, M. Amouroux, CRAN, CNRS, Nancy Univ. (France); Y. Guermeur, LORIA, CNRS, Nancy Univ. (France); W. C. P. M. Blondel, CRAN, CNRS, Nancy Univ. (France)

808710 Gold nanoparticles for tumour detection and treatment [8087-58]

L. Hartsuiker, W. Petersen, J. Jose, P. van Es, A. Lenferink, A. A. Poot, L. W. M. M. Terstappen, Univ. of Twente (Netherlands); T. G. van Leeuwen, Univ. of Twente (Netherlands) and Univ. of Amsterdam (Netherlands); S. Manohar, C. Otto, Univ. of Twente (Netherlands) 
8087 1T Testing possibilities for establishing nanodiamond-DNA-conjugates [8087-63]

A. Pohl, Fraunhofer-Institut für Zerstörungsfreie Prüfverfahren (Germany); S. Joch, Technische Univ. Dresden (Germany); J. Michael, Fraunhofer-Institut für Zerstörungsfreie Prüfverfahren (Germany); E. Boschke, P. Quenzel, Technische Univ. Dresden (Germany); J. Schreiber, Fraunhofer-Institut für Zerstörungsfreie Prüfverfahren (Germany); V. Lapina, B.I. Stepanov Institute of Physics (Belarus); J. Opitz, Fraunhofer-Institut für Zerstörungsfreie Prüfverfahren (Germany)

$80871 \mathrm{U}$ Two-channel microfluidic CARS: experimental quantification of pure vibrational contrast in CARS images [8087-64]

G. Bergner, Institute of Photonic Technology Jena e.V. (Germany) and Univ. of Osnabrück (Germany); T. Henkel, D. Akimov, Institute of Photonic Technology Jena e.V. (Germany); B. Dietzek, Institute of Photonic Technology Jena e.V. (Germany) and Friedrich-Schiller Univ. Jena (Germany); S. Schlücker, Univ. of Osnabrück (Germany); H. Bartelt, Institute of Photonic Technology Jena e.V. (Germany); J. Popp, Institute of Photonic Technology Jena e.V. (Germany) and Friedrich-Schiller Univ. Jena (Germany)

8087 IW Spectroscopic-tomography of biological membrane with high-spatial resolution by the imaging-type 2D Fourier spectroscopy [8087-66]

A. Inui, R. Tsutsumi, W. Qi, T. Takuma, I. Ishimaru, Kagawa Univ. (Japan)

$80871 \mathrm{X}$ Evaluation of haemoglobin changes of skin and muscle tissue of the calf induced by topical application of a nonivamide / nicoboxil cream [8087-67]

J. Warnecke, Univ. of Applied Sciences Koblenz (Germany); T. Wendt, German Sport Univ. (Germany); M. Schak, Univ. of Applied Sciences Koblenz (Germany); T. Schiffer, W. Bloch, German Sport Univ. (Germany); M. Kohl-Bareis, Univ. of Applied Sciences Koblenz (Germany)

$80871 Y$ Design of a tissue oxygenation monitor and verification on human skin [8087-68] H. Liu, Moor Instruments, Ltd. (United Kingdom); M. Kohl-Bareis, Univ. of Applied Sciences Koblenz (Germany) and Moor Instruments GmbH (Germany); X. Huang, Moor Instruments, Ltd. (United Kingdom)

$808712 \quad$ Novel assay for direct fluorescent imaging of sialidase activity [8087-69] A. Tomin, T. Shkandina, R. Bilyy, NAS of Ukraine (Ukraine)

808720 Spectral discrimination of serum from liver cancer and liver cirrhosis using Raman spectroscopy [8087-70]

T. Yang, X. Li, Shenyang Ligong Univ. (China); T. YU, R. Sun, Karlsruhe Univ. of Applied Sciences (Germany); S. Li, Solon High School (United States)

808721 Analysis of LIF-Raman spectroscopy for the diagnosis of normal and liver diseases [8087-71] X. Li, T. Yang, Shenyang Ligong Univ. (China); T. YU, R. Sun, Karlsruhe Univ. of Applied Sciences (Germany); S. Li, Solon High School (United States)

808722 Surface-enhanced Raman spectroscopy differences of saliva between lung cancer patients and normal people [8087-72]

X. Li, T. Yang, Shenyang Ligong Univ. (China); S. Li, Solon High School (United States); T. YU, Karlsruhe Univ. of Applied Sciences (Germany) 
808724 Real-time multispectral processing of biological objects images [8087-75]

V. V. Shapovalov, Saint Petersburg Electrotechnical Univ. (Russian Federation);

B. S. Gurevich, Scientific Instruments Co. (Russian Federation); S. V. Andreyev, Saint

Petersburg Electrotechnical Univ. (Russian Federation); A. V. Belyaev, Institute for Analytical Instrumentation (Russian Federation); V. N. Chelak, Saint Petersburg Electrotechnical Univ. (Russian Federation)

808725 The influence of $3 d^{3}$ type transition metals on light scattering properties of sulfur cycle bacteria Desulfuromonas acetoxidans [8087-76]

O. I. Bilyi, O. M. Vasyliv, S. O. Hnatush, V. B. Getman, Ivan Franko National Univ. of L'viv (Ukraine); G. I. Kotsyumbas, SSRCI of Veterinary Preparations and Fodder Additives (Ukraine)

808726 Image analysis of free diffusing nanoparticles in vitro [8087-77]

T. Wagner, S. O. Luettmann, D. Swarat, FH Dortmund (Germany); M. Wiemann, IBE RD gGmbH (Germany); H.-G. Lipinski, FH Dortmund (Germany)

808727 Discrimination of serum Raman spectroscopy between normal and colorectal cancer [8087-78]

X. Li, T. Yang, Shenyang Ligong Univ. (China); T. Yu, Karlsruhe Univ. of Applied Sciences (Germany); S. Li, Solon High School (United States)

808728 Detection of serum from lung cancer patients using auto-fluorescence [8087-79] X. Li, X. Tian, T. Yang, Shenyang Ligong Univ. (China); T. Yu, Karlsruhe Univ. of Applied Sciences (Germany); S. Li, Solon High School (United States)

\section{POSTER SESSION: SKIN DIAGNOSTICS AND THERAPY}

808729 Validation of a 2D multispectral camera: application to dermatology/cosmetology on a population covering five skin phototypes [8087-80]

R. Jolivot, Lab. Le2i, CNRS, Univ. de Bourgogne (France); H. Nugroho, Univ. Teknologi Petronas (Malaysia); P. Vabres, Lab. Le2i, CNRS, Univ. de Bourgogne (France) and Univ. Hospital, Dijon Cedex (France); M. H. Ahmad Fadzil, Univ. Teknologi Petronas (Malaysia); F. Marzani, Lab. Le2i, CNRS, Univ. de Bourgogne (France)

8087 2A Using MAP to recover the optical properties of a biological tissue from reflectance measurements [8087-81]

A. Zidouk, I. B. Styles, Univ. of Birmingham (United Kingdom)

8087 2B RGB mapping of hemoglobin distribution in skin [8087-82]

D. Jakovels, J. Spigulis, L. Rogule, Univ. of Latvia (Latvia)

$80872 \mathrm{C}$ Evaluation of a novel fiber probe for spatially and spectrally resolved reflectance measurements of turbid media [8087-83]

S. Andree, H. Luckmann, C. Reble, I. Gersonde, J. Helfmann, Laser- und Medizin-Technologie GmbH, Berlin (Germany)

8087 2D Development of a fiber-based Raman probe for clinical diagnostics [8087-84] I. Latka, S. Dochow, C. Krafft, Institute of Photonic Technology Jena e.V. (Germany); B. Dietzek, Institute of Photonic Technology Jena e.V. (Germany) and Friedrich-Schiller Univ. Jena (Germany); H. Bartelt, Institute of Photonic Technology Jena e.V. (Germany); J. Popp, Institute of Photonic Technology Jena e.V. (Germany) and Friedrich-Schiller Univ. Jena (Germany) 
8087 2E Multi-spectral photoplethysmography technique for parallel monitoring of pulse shapes at different tissue depths [8087-85]

L. Asare, E. Kviesis-Kipge, U. Rubins, O. Rubenis, J. Spigulis, Univ. of Latvia (Latvia)

$80872 \mathrm{~F} \quad$ Photobleaching measurements of pigmented and vascular skin lesions: results of a clinical trial [8087-86]

A. Lihachev, Univ. of Latvia (Latvia); K. Rozniece, Skin Diseases and Sexually Transmitted

Disease Clinic (Latvia); J. Lesins, J. Spigulis, Univ. of Latvia (Latvia)

8087 2G Melanoma-nevus differentiation by multispectral imaging [8087-87]

I. Diebele, I. Kuzmina, Univ. of Latvia (Latvia); J. Kapostinsh, A. Derjabo, Latvian Oncology

Ctr. (Latvia); J. Spigulis, Univ. of Latvia (Latvia)

$80872 \mathrm{H} \quad$ Bimodal spectroscopy for in vivo characterization of hypertrophic skin tissue: pre-clinical experimentation, spectral data selection and classification [8087-88]

H. Liu, Ctr. de Recherche en Automatique de Nancy, CNRS, Nancy Univ. (France);

H. Gisquet, Univ. Hospital of Nancy (France); F. Guillemin, Ctr. Alexis Vautrin (France);

W. C. P. M. Blondel, Ctr. de Recherche en Automatique de Nancy, CNRS, Nancy Univ.

(France)

\section{POSTER SESSION: CLINICAL AND PRECLINICAL TISSUE CHARACTERIZATION}

$808721 \quad$ Model-based spectral analysis of photon propagation through nanoparticle-labeled epithelial tissues [8087-89]

C. Cihan, Bilkent Univ. (Turkey); D. Arifler, Eastern Mediterranean Univ. (Cyprus)

8087 2J Spectral imaging as a potential tool for optical sentinel lymph node biopsies [8087-90]

J. D. O'Sullivan, P. R. Hoy, H. N. Rutt, Univ. of Southampton (United Kingdom)

$80872 \mathrm{~L} \quad$ Method to determine optimal illumination wavelengths for gold nanoparticle detection in tissue using reflectance spectroscopy [8087-92]

P. B. García-Allende, C. Barriere, V. S. Sauvage, J. Qi, D. S. Elson, Imperial College London (United Kingdom)

$80872 \mathrm{~N} \quad$ Preliminary results for hyperspectral videoendoscopy diagnostics on the phantoms of normal and abnormal tissues: towards gastrointestinal diagnostics [8087-95]

M. Hohmann, Friedrich-Alexander-Univ. Erlangen-Nürnberg (Germany); A. Douplik,

J. Varadhachari, Erlangen Graduate School in Advanced Optical Technologies (Germany) and Friedrich-Alexander-Univ. Erlangen-Nürnberg (Germany); A. Nasution, Institut Teknologi Sepuluh Nopember (Indonesia); J. Mudter, M. Neurath, Friedrich-Alexander-Univ. Erlangen-Nürnberg (Germany); M. Schmidt, Erlangen Graduate School in Advanced Optical Technologies (Germany) and Friedrich-Alexander-Univ. Erlangen-Nürnberg (Germany)

$80872 \mathrm{P} \quad$ In vivo determination of absorption and scattering properties in rat cerebral cortex using single reflectance fiber probe with two sourcecollector geometries [8087-97] I. Nishidate, Tokyo Univ. of Agriculture and Technology (Japan); S. Kawauchi, S. Sato, M. Ishihara, M. Kikuchi, National Defense Medical College (Japan); M. Sato, Yamagata Univ. (Japan) 
$80872 \mathrm{Q}$ Complex degree of mutual anisotropy of biological liquid crystals net [8087-99]

Y. A. Ushenko, O. V. Dubolazov, O. Y. Telenga, A. P. Angelsky, A. O. Karachevtcev,

$\checkmark$. Balanetska, Chernivtsi National Univ. (Ukraine)

808725 Imaging prosthetic implant related wear debris in macrophages using coherent anti-Stokes Raman scattering spectroscopy [8087-101]

M. Lee, A. Elfick, Univ. of Edinburgh (United Kingdom)

$80872 \mathrm{~T}$ Modeling and measuring extravascular hemoglobin: aging contusions [8087-103]

C. Lines, O. Kim, Univ. of Notre Dame (United States); S. Duffy, Rhode Island Hospital (United States); M. Alber, G. P. Crawford, Univ. of Notre Dame (United States)

$80872 \mathrm{U}$ Towards a realistic numerical modeling of polarimetric response of healthy and pathological colon tissue [8087-104]

M. R. Antonelli, A. Pierangelo, T. Novikova, LPICM, CNRS, Ecole Polytechnique (France):

P. Validire, A. Benali, B. Gayet, Institut Mutualiste Montsouris (France); A. De Martino, LPICM, CNRS, Ecole Polytechnique (France)

Author Index 
Downloaded From: https://www.spiedigitallibrary.org/conference-proceedings-of-spie on 25 Apr 2023

Terms of Use: https://www.spiedigitallibrary.org/terms-of-use 


\title{
Conference Committee
}

\author{
General Chairs
}

Christoph K. Hitzenberger, Medizinische Universität Wien (Austria)

Brian W. Pogue, Dartmouth University (United States)

Programme Chairs

Peter E. Andersen, Technical University of Denmark (Denmark)

Irene Georgakoudi, Tufts University (United States)

Conference Chairs

Nirmala Ramanujam, Duke University (United States)

Jürgen Popp, Institut für Photonische Technologien (Germany)

Programme Committee

Niels Bendsoe, Lund University Hospital (Sweden)

Andrew J. Berger, University of Rochester (United States)

Volker Deckert, Institut für Photonische Technologien (Germany)

Kishan Dholakia, University of Saint Andrews (United Kingdom)

Kristen Carlson Dawn Maitland, Texas A\&M University (United States)

Gregory M. Palmer, Duke University (United States)

Francesco Saverio Pavone, LENS Laboratorio, Università degli Studi di Firenze (Italy)

Lise Lyngsnes Randeberg, Norwegian University of Science and Technology (Norway)

Melissa C. Skala, Duke University (United States)

James Tunnel, The University of Texas at Austin (United States)

Urs Utzinger, The University of Arizona (United States)

Alastair J. M. Watson, Royal Liverpool and Broadgreen University Hospitals NHS Trust (United Kingdom)

Bing Yu, Duke University (United States)

Session Chairs

1 Minimally Invasive Diagnostics/Laboratory Medicine I

Jürgen Popp, Institut für Photonische Technologien e.V. (Germany)

2 Minimally Invasive Diagnostics/Laboratory Medicine II

Stephen A. Boppart, University of Illinois at Urbana-Champaign (United States) 
3 Biospectroscopy and POC Diagnostics I

Stephen A. Boppart, University of Illinois at Urbana-Champaign (United States)

4 Biospectroscopy and POC Diagnostics II

Bing Yu, Duke University (United States)

$5 \quad$ Clinical and Preclinical Tissue Characterization I

Franck Bonnier, Dublin Institute of Technology (Ireland)

6 Clinical and Preclinical Tissue Characterization II

Henricus J. C. M. Sterenborg, Erasmus MC (Netherlands)

$7 \quad$ Clinical and Preclinical Tissue Characterization III

Lise Lyngsnes Randeberg, Norwegian University of Science and Technology (Norway)

8 Clinical and Preclinical Tissue Characterization IV

Malini C. Olivo, National University of Ireland, Galway (Ireland)

$9 \quad$ Skin Diagnostics and Therapy I

Martin C. Fischer, Duke University (United States)

10 Skin Diagnostics and Therapy II

Martin C. Fischer, Duke University (United States)

11 Clinical and Preclinical Diagnostics I

J. Quincy Brown, Duke University (United States)

12 Clinical and Preclinical Diagnostics II

Martin J. Leahy, University of Limerick (Ireland)

13 Clinical and Preclinical Diagnostics III

Francesco Baldini, Istituto di Fisica Applicata Nello Carrara (Italy) 


\section{Introduction}

Spectroscopic methods have become most valuable tools for both clinical diagnostics and biomedical research applied to in vivo tissue monitoring and the investigation on the molecular scale of excised samples. In clinical diagnostics, optical spectroscopy provides detailed structural and functional information on organs, tissues and body liquids. Basic biomedical applications include the detailed investigation of tissues and cells down to the level of single molecules, helping to understand the principles of cellular and sub-cellular processes in the early transformation of normal to diseased tissue, such as when malignant tumours are developed.

The conference provided an interdisciplinary platform for physicians, physicists, biologists, chemists and related researchers in order to strengthen an integrated and holistic approach of understanding normal tissue development and the genesis of diseases in order to be able to ultimately develop new, efficient treatment modalities.

Contributed papers are solicited, but not limited, to the following areas: using optical spectroscopy methods, e.g. fluorescence, autofluorescence, linear and nonlinear Raman, NIR, polarization, back-reflectance, and light scattering spectroscopy, and combined approaches (multimodal imaging):

\section{Biomedical and clinical spectroscopic diagnostics}

In vivo diagnostics (structural and functional spectral imaging of cells, tissues, organs), including endoscopic, noninvasive and minimally invasive methods Tissue pathology Spectral biomarker analysis Spectroscopic micro- and nanosensors Biochip technology for point-of-care diagnostics Diagnostics and tissue engineering

\section{Investigation of cellular and sub-cellular processes}

Analysis of cell dynamics by single-molecule techniques

High spatial resolution microscopy

Structural analysis of cells and tissue

Biomarker discovery for spectroscopic techniques 
Downloaded From: https://www.spiedigitallibrary.org/conference-proceedings-of-spie on 25 Apr 2023

Terms of Use: https://www.spiedigitallibrary.org/terms-of-use 